Hadi Peristiwo

\title{
ENTREPRENEURIAL QUOTIENT (ENTRE-Q): KECERDASAN WIRAUSAHA
}

\begin{abstract}
Abstrak
Seorang wirausahawan yang memiliki kecerdasan yang optimal akan memiliki peluang untuk mencapai kesuksesan. Dalam hal ini terdapat perbedaan antara kecerdasan emosional dan kecerdasan intelektual. Daniel Goleman mengungkapkan bahwa kecerdasan intelektual yang dimiliki oleh sesorang merupakan bakat turunan yang tidak dapat untuk diubah, serta merupakan ciri bawaan seseorang sejak lahir. Sedangkan yang dimaksud dengan kecerdasan emosional adalah jembatan (gate) antara apa yang seseorang tersebut ketahui dengan apa yang seseorang tersebut lakukan.

Emosi bisnis bagi seorang wirausahawan sangat penting, dalam hal ini emosi yang bersifat positif. Emosi dapat memacu seseorang untuk melakukan proses kreatifitas dan inovasi. Emosi yang utama dalam kesuksesan wirausaha adalah antusiasme. Bisnis tanpa disertai dengan emosi seolah tidak memiliki gairah. Hal tersebut yang membuat individu tidak memiliki nyali serta keberanian untuk melakukan kegiatan berwirausaha, apalagi bersaing dengan wirausahawan lain yang sama-sama menjual produk yang sejenis. Mereka yang bisa eksis dan bertahan dalam melakukan usaha bisnis adalah mereka yang menang dalam persaingan.

Jiwa kreatif merupakan kunci utama dalam menggapai sebuah kesuksesan. Ketika seseorang memiliki jiwa kreatif, maka tentu akan terus berkarya. Kreatifitas dari wirausahawan sangat dibutuhkan dalam dunia usaha karena semakin meningkatnya persaingan dari berbagai lingkungan bisnis.

Setiap orang harus berani memulai atau mengembangkan bisnisnya sendiri. Hal inilah yang disebut dengan kecerdasan wirausaha atau entrepreneurial quotient (Entre-Q).Sebagian besar wirausaha yang memiliki Entre-Q selalu mengedepankan semangat dan kecerdasan setiap menghadapi tantangan, hal ini biasanya dibangun melalui pemikiran-pemikiran dari wirausahawan tersebut.
\end{abstract}

Kata Kunci: Entrepreneurial quotient, wirausaha.

\section{Pendahuluan}

Daniel Goleman adalah orang yang pertama memperkenalkan mengenai kecerdasan emosional. Dalam bukunya Emotional Intelligence, ia mengungkapkan 
bahwa terdapat lima wilayah kecerdasan emosi yaitu: mengenali emosi diri, mengelola emosi, memotivasi diri sendiri, mengenal emosi orang lain dan membina hubungan. Bila seseorang mampu memahami dan mengelola kelima wilayah utama kecerdasan emosional tersebut maka kegiatan bisnis apa pun yang dilakukan akan berpeluang untuk dapat berhasil dan sukses. Dalam hal ini terdapat perbedaan antara kecerdasan emosional dan kecerdasan intelektual. Daniel Goleman mengungkapkan bahwa kecerdasan intelektual yang dimiliki oleh sesorang merupakan bakat turunan yang tidak dapat untuk dirubah, serta merupakan ciri bawaan seseorang sejak lahir. Sedangkan yang dimaksud dengan kecerdasan emosional adalah jembatan (gate) antara apa yang seseorang tersebut ketahui dengan apa yang seseorang tersebut lakukan. Semakin tinggi tingkat kecerdasan emosional maka akan semakin terampil melakukan sesuatu yang diketahuinya adalah benar. Kecerdasan ini pada umumnya telah dimiliki oleh generasi pertama family business. ${ }^{1}$

Seorang wirausahawan yang memiliki kecerdasan emosional yang optimal akan memiliki peluang untuk mencapai kesuksesan. Simund Freud mengatakan, keinginan untuk menjadi orang sukses merupakan keinginan untuk menjadi orang yang yang dihormati. ${ }^{2}$ Pengertian dari kata sukses sangat relatif, setiap individu dapat menafsirkan secara berbeda-beda karena memiliki latar belakang pendidikan, pengalaman, budaya, status sosial dan ekonomi yang berbeda-beda pula. Kata sukses mempunyai dimensi yang beragam atau multidimensional sehingga setiap orang akan menilai dari satu atau beberapa sisi yang berlainan.

Kecerdasan emosional optimal yang dimiliki oleh seseorang dapat ditransformasikan jika menghadapi situasi yang sulit, dimana akan peka terhadap peluang usaha serta dapat mengatasi konflik, lebih mampu untuk mengatur strategi bisnis, memiliki kepekaan, kreatifitas dan inovatif serta komitmen yang tinggi dalam menjalankan usaha. Wirausahawan perlu memiliki kecerdasan emosional yang optimal, sulit bagi seseorang yang memiliki kecerdasan intelektual yang tinggi untuk menjadi wirausaha yang berhasil jika kecerdasan emosionalnya rendah.

\section{Emosi Bisnis Dalam Berwirausaha}

Emosi bisnis bagi seorang wirausahawan sangat penting, dalam hal ini emosi yang bersifat positif. Emosi dapat memacu seseorang untuk melakukan proses kreatifitas dan inovasi. Emosi yang utama dalam kesuksesan wirausaha adalah antusiasme. ${ }^{3}$ Emosi pun dapat mengaktifkan nilai-nilai etika serta mendorong dan mempercepat penalaran pikiran seseorang dalam menjalankan aktivitas bisnis. Emosi pun dapat memotivasi dan membuat seseorang merasa lebih hidup.

Dalam bahasa latin, emosi disebut motus anima yang artinya "jiwa yang menggerakkan kita". Banyak para pelaku wirausaha yang belum menyadari dan menghargai peran penting dari emosi. Orang terkadang menyikapi arti dari emosi sebagai makna konvensional, dalam arti emosi adalah suatu kelemahan dan tidak boleh ada dalam kegiatan bisnis, bahkan orang cenderung untuk menghindari orang 
yang emosional. Pikiran emosional dapat menyebabkan seseorang bereaksi, bukan karena berpikir. ${ }^{4}$ Hanya bentuk pikiran dan kata-kata tanpa emosi yang sering lebih diperhatikan. Padahal emosi menurut praktisi wirausaha merupakan sebuah sumber energi dan bisa dikatakan energi adalah bahan-bakar.

Bisnis tanpa disertai dengan emosi seolah tidak memiliki gairah. Hal tersebut yang membuat individu tidak memiliki nyali serta keberanian untuk melakukan kegiatan berwirausaha, apalagi bersaing dengan wirausahawan lain yang sama-sama menjual produk yang sejenis. Mereka yang bisa eksis dan bertahan dalam melakukan usaha bisnis adalah mereka yang menang dalam persaingan.

Seorang wirausahawan seharusnya lebih memiliki minat pada sesuatu yang memiliki makna penting daripada makna konvensional yang biasa-biasa saja. Sikap kepasrahan terhadap lingkungan usaha akan menjadikan pelaku wirausaha tidak memiliki keberanian untuk menghadapi tantangan usaha serta tidak berpikir kreatif. Emosi dalam wirausaha bukanlah lambang kelemahan, akan tetapi merupakan lambang kekuatan dalam bisnis. Kerja keras dan sikap pantang menyerah adalah formulasi yang ampuh dalam membuat wirausahawan menjadi orang sukses. ${ }^{5}$

Sikap emosi negatif akibat kegagalan dalam menjalankan wirausaha bukanlah merupakan suatu nilai yang positif, kegagalan-kegagalan yang dialami oleh wirausahawan dapat dijadikan sebagai suatu media pembelajaran untuk wirausahawan tersebut melanjutkan perjuangan menjalankan bisnisnya sehingga di lain waktu tidak akan terjatuh kembali kepada kegagalan yang sama.

Kegagalan dijadikan sebagai sumber motivasi dan dapat dijadikan sebagai paradigma untuk tidak takut melangkah. Proses kegagalan bukan terjadi di saat gagal dalam berusaha untuk mencapai keinginan melainkan kegagalan adalah jika memutuskan berhenti untuk berjuang untuk mencapai keinginan dan impian.

\section{Sinergi Otak Berpikir Dan Otak Emosional Wirausaha}

Penelitian mengenai otak dan perilaku sangat menarik untuk dikaji lebih mendalam. Menurut hasil penelitian, seseorang memiliki dua otak, yaitu satu yang berpikir (otak berpikir) dan yang satu yang merasakan (otak emosional). Otak berpikir biasa disebut dengan otak kiri, sementara otak emosional disebut dengan otak kanan.

Dikotomi definisi otak emosional dengan otak berpikir kurang lebih sama dengan istiah "hati" dengan "kepala", yaitu mana yang lebih dahulu terjadi. Menurut hasil penelitian, otak emosional ternyata terjadi lebih dahulu sebelum otak berpikir

Hasil penelitian yang dilakukan mengingatkan bahwa dalam menggeluti dunia usaha, seseorang seharusnya dapat menyelaskan otak berpikir dengan otak emosional. Keselarasan kedua otak itu sangat dibutuhkan terutama dalam mengambil keputusan bisnis. Dengan keselarasan tersebut, seorang wirausahawan akan lebih tepat dan bersikap bijaksana dalam mengambil sebuah keputusan bisnis. Kedua otak tersebut pada umumnya bekerja pada tingkat keselarasan yang erat, saling melengkapi, saling 
terkait dimana emosi memberi masukan dan informasi kepada proses berpikir atau pikiran rasional. Sementara pikiran rasional memperbaiki dan terkadang memveto masukan emosi tersebut. ${ }^{6}$

Wirausaha harus menjaga keselarasan kedua otak tersebut, dimana perasaan atau emosi sangat dibutuhkan didalam mengambil sebuah keputusan yang rasional dan tepat. Dampak positif dari terciptanya keselarasan kedua otak tersebut adalah munculnya tindakan-tindakan produktif. Salah satu kunci keberhasilan dalam wirausaha adalah dengan memiliki dua hal terpenting dalam kehidupan usaha yaitu kemampuan dan kemauan. ${ }^{7}$ Keselarasan akan membuat seorang wirausaha semakin mantap dalam berbisnis yang pada akhirnya akan berdampak positif bagi kemajuan bisnis.

Keselarasan otak kiri dan kanan tidak akan terwujud bila wirausahawan masih memegang teguh sifat mementingkan diri sendiri (egois). Wirausahawan yang dapat menyelaraskan otak berpikir dan otak emosional memiliki kemungkinan lebih besar untuk dapat berhasil dalam kegiatan usaha. Peluang menjadi wirausaha yang berkompeten, handal, bernilai, profesional serta bahagia lebih besar. Meski sangat tidak mudah untuk dapat menyelaraskan kedua otak tersebut, namun seorang wirausaha yang tanggung harus dapat berani untuk dapat mencobanya.

\section{Karakter Wirausaha}

Sukses atau tidaknya seorang wirausaha dalam mengelola usaha tidak hanya dipengaruhi oleh banyaknya modal yang dimiliki serta fasilitas atau koneksi dengan seseorang yang dianggap memiliki kekuasaan. Satu hal yang penting adalah bahwa usaha dikelola oleh orang-orang yang berjiwa wirausaha dan mengerti apa yang dilakukan, mengapa dan bagaimana bisnis tersebut dapat dijalankan dan dikelola dengan baik. ${ }^{8}$

\section{Tabel 1. Karakteristik Profil Wirausaha}

\begin{tabular}{|l|l|}
\hline Karakteristik Profil & \multicolumn{1}{c|}{ Ciri Wirausahawan yang Menonjol } \\
\hline Berprestasi tinggi & Ahli untuk memperoleh prestasi \\
\hline Pengambil resiko & $\begin{array}{l}\text { Mereka tidak takut mengambil resiko akan tetapi } \\
\text { menghindari risiko tinggi apabila dimungkinkan }\end{array}$ \\
\hline Pemecah masalah & $\begin{array}{l}\text { Mereka tanggap mengenali dan memecahkan masalah yang } \\
\text { dapat menghalangi kemampuan mencapai tujuan }\end{array}$ \\
\hline Pencari status & $\begin{array}{l}\text { Mereka tidak memperkenankan kebutuhan terhadap status } \\
\text { yang mengganggu misi usahanya }\end{array}$ \\
\hline $\begin{array}{l}\text { Tingkatan energi } \\
\text { tinggi }\end{array}$ & Dedikasi dan workoholic demi wujudnya sukses \\
\hline Percaya diri & Tingkat confidence yang tinggi \\
\hline Ikatan emosi & Memisahkan antara hubungan emosional dan karir \\
\hline
\end{tabular}




\begin{tabular}{|l|l|}
\hline Karakteristik Profil & \multicolumn{1}{|c|}{ Ciri Wirausahawan yang Menonjol } \\
\hline Kepuasan pribadi & $\begin{array}{l}\text { Menyukai kompleksitas tinggi dengan formulasi yang } \\
\text { rendah }\end{array}$ \\
\hline
\end{tabular}

Karakteristik sukses wirausaha yang perlu ditanamkan adalah bagaimana berpikir objektif dan kreatif sehingga mampu untuk menganalisis setiap kesempatan bisnis yang muncul dan pengendalian diri yang matang sehingga mampu untuk merencanakan dan mengendalikan bisnis secara objektif dan tidak mengandalkan pertolongan serta fasilitas yang ada di luar kemampuan atau mengandalkan fasilitas atau kemudahan serta koneksi dari pihak lain.

Kelebihan modal atau fasilitas yang dimiliki oleh wirausahawan karena dekat dengan pimpinan kekuasaan pada umumnya tidak menjamin bahwa usahanya tersebut akan sukses dalam jangka panjang. Terdapat banyak bukti menunjukkan bisnis yang maju karena suatu konektifitas serta fasilitas yang diberikan ternyata tidak mampu untuk bertahan hidup lama. ${ }^{9}$

Pada akhirnya seorang wirausahawan harus berpikir realistis, praktis serta bersikap optimis. Realistis berarti harus melihat sesuatu berdasarkan kenyataan yang ada, sedangkan berpikir praktis berarti dapat mengerjakan sesuatu yang ada pada saat ini dilakukan. Bersikap optimis sebagai langkah awal dalam menjalankan usaha bisnis. Berawal dari pemikiran dan sikap yang optimis serta tidak mudah putus asa akan menjadi kekuatan (power) dalam menjalani persaingan usaha.

\section{Gambar 1. Relasi Faktor-Faktor Pembentuk Wirausahawan}

$$
\begin{aligned}
& \text { Keterangan : } \\
& =\text { Seluruhan relasi pembentuk } \\
& =\text { Kreatifitas } \\
& \square=\text { Motivasi dan inovasi } \\
& \square=\text { Agresivitas } \\
& \square=\text { Risk seeker } \\
& =\text { Integritas kepribadian } \\
& =\text { Percaya diri } \\
& =\text { Kompetensi } \\
& =\text { Pemecah masalah }
\end{aligned}
$$

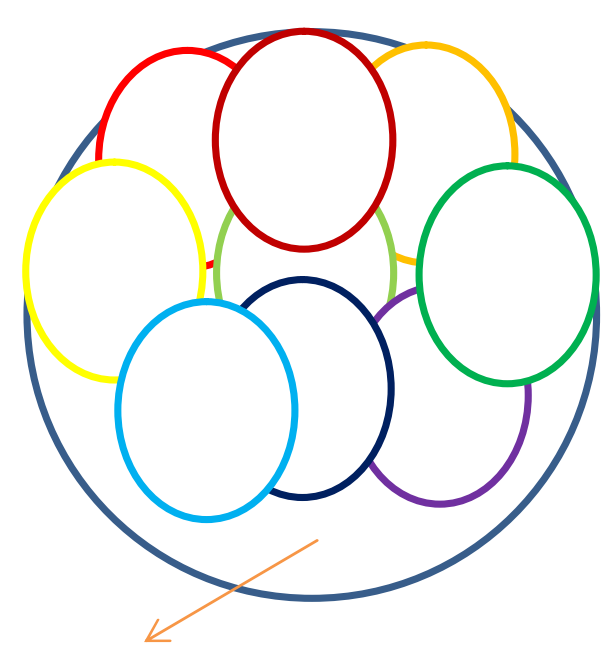

Wirausahawan 


\section{Kreatif Versus Inovatif}

Kesuksesan berasal dari jiwa kreatif seseorang yang terus berjuang untuk mencapai kesempurnaan dalam penciptaannya. Jiwa kreatif adalah merupakan kunci utama dalam menggapai sebuah kesuksesan. Ketika seseorang memiliki jiwa kreatif, maka tentu akan terus berkarya. Kreatifitas dari wirausahawan sangat dibutuhkan dalam dunia usaha karena semakin meningkatnya persaingan dari berbagai lingkungan bisnis.

Manusia terlahir sebagai mahluk yang paling sempurna diantara mahluk hidup yang lain. Hal ini disebabkan oleh karena manusia dianugerahi akal dan pikiran untuk berpikir. Maka sangat pantas jika terdapat orang yang berpikiran kritis dalam hidupnya. Bersikap kritis merupakan suatu hal yang positif, akan tetapi sikap kritis tanpa berpikir bagaimana cara menyelesaikan masalah bukan merupakan suatu hal yang bijak. Mahakarya yang penting dari seseorang wirausaha adalah terciptanya ide, gagasan dan pikiran yang cemerlang.

Sedangkan inovatif adalah bakat, seperti halnya seniman yang menghasilkan karya seni tertentu, hal tersebut sulit untuk dipelajari atau diajarkan. Proses inovatif merupakan suatu proses imajiner dimana dalam hal ini wirausaha harus dapat menciptakan sebuah formula produk bisnis yang belum pernah ada sebelumnya di lingkungan bisnis. ${ }^{10}$

Tabel 2. Kreatif VS Inovatif

\begin{tabular}{|l|l|}
\hline \multicolumn{1}{|c|}{ KREATIF } & \multicolumn{1}{c|}{ INOVATIF } \\
\hline Memiliki daya cipta/berdaya cipta & Berdaya perubahan/pembaruan \\
\hline $\begin{array}{l}\text { a. Menciptakan sesuatu yang berbeda } \\
\text { dari yang lain. }\end{array}$ & $\begin{array}{l}\text { a. Menciptakan sesuatu yang belum ada } \\
\text { menjadi ada. } \\
\text { b. Menghubungkan ide-ide/hal-hal } \\
\text { yang tadinya tidak berhubungan. }\end{array}$ \\
\hline $\begin{array}{l}\text { Contoh ide kreatif: Grup 2 Tang } \\
\text { menghasilkan produk air putih dengan } \\
\text { kemasan plastik yang berbeda (tutup } \\
\text { anti tumpah). }\end{array}$ & $\begin{array}{l}\text { Contoh inovasi: Alm. Tirto Utomo } \\
\text { mengemas air putih dalam kemasan } \\
\text { plastik yang diberi merk Aqua. }\end{array}$ \\
\hline
\end{tabular}

Dalam berwirausaha proses kreatif dan inovatif mutlak untuk dilakukan jika tidak ingin bisnis atau wirausaha tersebut terhenti. Hambatan-hambatan dalam berpikir kreatif dan inovatif terus dihilangkan dengan melakukan persiapan seperti pendidikan formal dan informal mengenai entrepreneurship (berkewirausahaan), mengumpulkan ide sebanyak mungkin, menggabungkan ide-ide yang sudah ada sehingga muncul ide atau embrio ide yang baru dengan menggunakan inkubasi serta memahami persoalan/permasalahan bisnis secara mendalam. ${ }^{11}$ 


\section{Wirausaha Kreatif}

Wirausaha merupakan dunia yang sangat unik, karena menuntut wirausahawan untuk dapat selalu bersikap kreatif. Dari kreatifitas akan terbukti bahwa wirausahawan memiliki kemandirian yang dapat membuat orang lain untuk dapat mengikuti jejak bisnis dari wirausahawan tersebut.

Menjadi wirausahawan yang kreatif di saat krisis merupakan tantangan yang sangat berat. Seseorang yang akan terjun menjadi wirausaha kreatif harus bekerja 24 jam sehari dan 7 hari dalam waktu seminggu. Kondisi tersebut harus dilakukan oleh seorang wirausahawan paling sedikit untuk kurun waktu kurang lebih 2 (dua) tahun.

Bisnis modern tidak mungkin dapat hidup dan berkembang bila tidak ditunjang oleh kemampuan menciptakan sesuatu yang baru setiap hari, walaupun hal tersebut merupakan hasil penggabungan dari berbagai unsur yang ada sebelumnya sehingga kemudian menjadi suatu bentuk baru yang berbeda dengan bentuk yang lain. Dari kreatifitas akan muncul barang, jasa ataupun ide baru sebagai inovasi baru, untuk memenuhi kebutuhan pasar yang terus berkembang. Dari kreatifitas tersebut akan muncul pula cara-cara baru, mekanisme kerja ataupun metode-metode usaha baru untuk dapat lebih meningkatkan efisiensi dan produktifitas.

\section{Mengembangkan Entre-Q}

Sebagian orang berpendapat bahwa sistem pendidikan di Indonesia harus segera direvisi, karena selama ini pendidikan yang digunakan membuat seseorang takut untuk berbuat sesuatu. Sejak pendidikan sekolah dasar, guru selalu mengharuskan siswa untuk mengerjakan segala sesuatu tanpa salah. Padahal semakin banyak membuat kesalahan, orang dapat semakin banyak belajar dari kesalahan tersebut. Anak didik juga diharuskan untuk dapat menghafal pelajaran dan menghitung angka, bukan bagaimana diajarkan mengenai cara berkomunikasi dengan baik, bagaimana memimpin maupun bagaimana bekerjasama. Akibatnya, pendidikan sekolah justru mengerdilkan kecerdasan wirausaha.

Akibatnya, seseorang yang ingin masuk ke dalam dunia bisnis selalu dihantui oleh perasaan takut untuk dapat berbuat sesuatu. Padahal tidak ada salahnya orang tersebut belajar dari kesalahan yang pernah diperbuat. Setiap orang harus berani memulai atau mengembangkan bisnisnya sendiri. Hal inilah yang disebut dengan kecerdasan wirausaha atau entrepreneurial quotient (Entre-Q).

Sebagian besar wirausaha yang memiliki Entre- $Q$ selalu mengedepankan semangat dan kecerdasan saat menghadapi tantangan, hal ini biasanya dibangun melalui pemikiran-pemikiran dari wirausahawan tersebut. Sosok wirausaha yang memiliki Entre- $Q$ selain memiliki kelebihan dalam cara berpikir, akan tetapi juga cerdas secara emosi, memiliki kreatifitas, intuisi serta cerdas dalam hal spiritualitas. Entre- $Q$ dapat dikembangkan dengan memperbanyak pengalaman serta praktik, dan banyak mencoba secara langsung. 


\section{Catatan Akhir:}

${ }^{1}$ Andreas Winardi, 7 Kunci Sukses Family Business, (Yogyakarta: Penerbit Andi, 2012).

${ }^{2}$ Syahrial Yusuf, Dari titik Nol 5 Strategi Ampuh Menjadi Pengusaha Sukses, (Jakarta: Visimedia, 2011).

${ }^{3}$ Meyer Silaban, Breaking The Rejection (Taktik Jitu Mengatasi dan Memanfaatkan Penolakan), (Jakarta: Penerbit PT.Gramedia Pustaka Utama, 2009).

${ }^{4}$ Robert T Kiyosaki, Sharon L. Lechter CPA, The Cashflow Quadrant (Panduan Ayah Kaya Menuju Kebebasan Finansial), (Jakarta: Penerbit PT. Gramedia Pustaka Utama, 2001).

${ }^{5}$ Prio Suyogi, 30 Jurus Berani Jadi Wirausahawan Mandiri, (Jakarta: MedPress, 2010).

${ }^{6}$ Sunarya, Abas PO, Sudaryono, Asep Saefullah, Kewirausahaan, (Yogyakarta: Penerbit Andi, 2011).

${ }^{7}$ Ilham Buchori, 40 Kisah Karyawan jadi Pengusaha, (Palembang: Maxikom, 2010).

${ }^{8}$ Direktorat Jenderal Pembelajaran dan Kemahasiswaan Ditjen Pendidikan Tinggi Kementerian Pendidikan dan Kebudayaan, Kewirausahaan (Modul Pembelajaran), ( Jakarta: Kemendikbud, 2013).

${ }^{9}$ Ibid.

${ }^{10}$ Leonardus Saiman, Kewirausahaan (Teori, Praktik dan Kasus-Kasus), (Jakarta: Penerbit Salemba Empat, 2009).

${ }^{11}$ Kasmir, Kewirausahaan, (Jakarta: PT.RajaGrafindo Persada, 2013). 


\section{DAFTAR PUSTAKA}

Buchori, Ilham, 40 Kisah Karyawan jadi Pengusaha, Palembang: Maxikom, 2010.

Direktorat Jenderal Pembelajaran dan Kemahasiswaan Ditjen Pendidikan Tinggi

Kementerian Pendidikan dan Kebudayaan, Kewirausahaan (Modul Pembelajaran), Jakarta, 2013.

Kasmir, Kewirausahaan, Jakarta: PT.RajaGrafindo Persada, 2013.

Kiyosaki, T Robert, Sharon L.Lechter CPA, The Cashflow Quadrant (Panduan Ayah Kaya Menuju Kebebasan Finansial), Jakarta: Penerbit PT. Gramedia Pustaka Utama, 2001.

Saiman, Leonardus, Kewirausahaan (Teori, Praktik dan Kasus-Kasus), Jakarta: Penerbit Salemba Empat, 2009.

Silaban, Meyer, Breaking The Rejection (Taktik Jitu Mengatasi dan Memanfaatkan Penolakan), Jakarta: Penerbit PT.Gramedia Pustaka Utama, 2009.

Sunarya, Abas PO, Sudaryono, Asep Saefullah, Kewirausahaan, Yogyakarta: Penerbit Andi, 2011.

Suyogi, Prio, 30 Jurus Berani Jadi Wirausahawan Mandiri, Jakarta: MedPress, 2010.

Winardi, Andreas, 7 Kunci Sukses Family Business, Yogyakarta: Penerbit Andi, 2012.

Yusuf, Syahrial, Dari titik Nol 5 Strategi Ampuh Menjadi Pengusaha Sukses, Jakarta: Visimedia, 2011.

Hadi Peristiwo, dosen pada Fakultas Syari'ah dan Ekonomi Islam IAIN Sultan Maulana Hasanuddin Banten. 